\title{
Formulasi Sediaan Gel Dari Serbuk Getah Pepaya (Carica papaya L.) Untuk Pengobatan Tumit Pecah-Pecah
}

\section{Preparations Gel Formulation Of Gum Powder Papaya (Carica papaya L.) For the Treatment of Cracked Heels}

\author{
Imas Maesaroh $^{1}$, Rima Yulia Senja ${ }^{1}$, Silvi Anggraeni ${ }^{1}$ \\ ${ }^{1}$ Akademi Farmasi Muhammadiyah Kuningan \\ Jl. Raya Cigugur Cirendang no d \\ Email : qiemz_31@yahoo.com
}

\begin{abstract}
ABSTRAK
Telah dilakukan penelitian "Formulasi Sediaan Gel Dari Serbuk Getah Pepaya (Carica papaya L.) Untuk Pengobatan Tumit Pecah-pecah" yang dibuat tiga formula dengan memvariasikan konsentrasi serbuk getah papaya. Penelitian ini bertujuan menentukan formula gel yang paling baik berdasarkan uji stabilitas fisik. Pada penelitian ini, pembuatan optimasi basis gel menggunakan Na-CMC konsentrasi Na-CMC $3 \%, 4 \%$, dan 5\%. Hasil optimasi gel diketahui bahwa formula dengan Na-CMC 3\% lebih stabil dan mempunyai karakteristik gel yang sesuai. Selanjutnya pembuatan gel serbuk getah pepaya dengan konsentrasi serbuk getah pepaya 4\%, 5\% dan 6\%. Gel kemudian diamati organoleptis, homogenitas, $\mathrm{pH}$, stabilitas fisik selama penyimpanan pada suhu lemari pendingin $10^{\circ} \mathrm{C}$ dan suhu kamar $30^{\circ} \mathrm{C}$, cycling test, dan uji hedonik. Berdasarkan hasil uji stabilitas fisik gel selama penyimpanan 28 hari, bahwa sediaan gel serbuk getah pepaya yang paling stabil yaitu gel dengan konsentrasi getah pepaya $4 \%$ dan $5 \%$ dalam penyimpanan suhu $30^{\circ} \mathrm{C}$. Gel tidak mengalami perubahan mulai dari warna, bau, kekentalan dan $\mathrm{pH}$. Hasil uji hedonik menunjukan bahwa persentase tingkat kesukaan formula 1, 2 dan 3 berturut-turut 68,46\%; $65 \%$ dan 69,23\%. Dilihat dari uji stabilitas fisik, cycling test dan uji hedonik disimpulkan gel formula $1(4 \%)$ merupakan formulasi paling baik sebagai gel untuk pengobatan tumit pecah-pecah.
\end{abstract}

Kata kunci : Gel, serbuk getah pepaya, dan uji stabilitas.

\begin{abstract}
Has conducted research "Preparations Gel Formulation Of Gum Powder Papaya (Carica papaya L.) For The Treatment Of Heel Cracking" made three formulas with varying concentrations of papaya latex powder. This study aims to determine the most good gel formula is based on physical stability test. In this research, manufacturing optimization using a gel base $\mathrm{Na}-\mathrm{Na}-\mathrm{CMC} \mathrm{CMC} \mathrm{concentration} \mathrm{of} \mathrm{3 \% ,} \mathrm{4 \%} \mathrm{and} \mathrm{5 \% .} \mathrm{The} \mathrm{result} \mathrm{of} \mathrm{optimization} \mathrm{is}$ known that the gel formula with $3 \% \mathrm{Na}-\mathrm{CMC}$ is more stable and has the characteristics of an appropriate gel. Further gelling papaya latex powder with papaya latex powder concentration of $4 \%, 5 \%$ and $6 \%$. Gel is then observed organoleptic, homogeneity, $\mathrm{pH}$, physical stability
\end{abstract}


during storage at refrigerator temperature $10^{\circ} \mathrm{C}$ and $30^{\circ} \mathrm{C}$ room temperature, cycling test, and hedonic test. Based on the test results of the physical stability of the gel during storage of 28 days, that papaya latex powder gel formulation of the most stable, papaya latex gel with a concentration of $4 \%$ and $5 \%$ in storage $30^{\circ} \mathrm{C}$. Gel unchanged from the color, odor, viscosity and $\mathrm{pH}$. The test results showed that the percentage of hedonic preference level formula 1,2 and 3 respectively $68.46 \% ; 65 \%$ and $69.23 \%$. Judging from the physical stability test, cycling test and hedonic test concluded gel formula $1(4 \%)$ is most excellent as a gel formulation for the treatment of cracked heels.

Keywords: Gel, papaya latex powder, and a stability test.

\section{PENDAHULUAN}

Kaki merupakan penanda kecantikan bagi seorang wanita. Kaki yang sehat adalah kaki yang bersih, mulus dan bercahaya, tidak kering pecah-pecah dan tidak berjamur. Namun, karena sering diabaikan berbagai masalah dapat timbul pada kaki. Dengan kaki yang halus dan mulus, maka kepercayaan diri kita akan semakin meningkat dan setidaknya merasa cantik.

Gangguan yang sering terasa di kaki adalah kulit tumit yang pecah-pecah. Gangguan ini jika tidak ditangani akan menjadi penyakit yang mengganggu penampilan, termasuk memberi rasa sakit. Tumit yang pecah-pecah menjadi salah satu masalah kulit yang dialami sebagian besar wanita, tapi sering diabaikan. Tidak hanya mengganggu penampilan, masalah ini juga bisa menyebabkan sakit karena lecet dan iritasi. Oleh karena itu, wanita yang memiliki kulit tumit pecah saat menggunakan sendal akan merasa kurang percaya diri (PD). Tumit pecahpecah tidak hanya menimpa golongan orang yang telah dewasa, bahkan remaja pun juga bisa terjangkit gejala tumit ini (NS Salika2010).

Batang, daun, dan buah pepaya mengandung getah berwarna putih yang mengandung enzim pemecah protein atau proteolitik dan populer dengan sebutan papain. Enzim ini banyak digunakan dalam berbagai kegiatan industri, seperti industri farmasi sebagai bahan obat, kosmetik, tekstil, penyamakan kulit dan lainnya. Namun sayang, hanya sebagian kecil masyarakat kita yang melakukan budidaya pepaya tersebut.

Pada kosmetika getah papaya dapat dimanfaatkan sebagai bahan aktif untuk krim, pembersih kulit muka, mengatasi pecah-pecah pada kulit, menghaluskan kulit, menguatkan jaringan agar lebih kenyal, karena papain bisa melarutkan sel-sel mati yang melekat pada kulit dan sukar terlepas secara fisik. Noda dan flek di wajah juga bisa dikikis oleh papain hingga menjadi mulus dan bersih.

Gloria Murtini, et al (2013) telah membuat formula tentang formula gel serbuk getah pepaya untuk mengobati keratoderma pada kulit dengan menggunakan basis karbopol 940 dan konsentrasi papain 5\%. Untuk memaksimalkan perawatan kulit atau keratoderma khususnya untuk kulit tumit pecah-pecah, perlu dikembangkan lebih lanjut produk keratoderma yang berasal dari bahan alam, salah satunya adalah getah pepaya. Produk untuk tumit pecah-pecah yang sudah beredar di pasaran berupa krim.

Sediaan gel memiliki sifat mudah menyebar, mudah dicuci dengan air, pelepasan obatnya baik, sediaan jernih yang elegan. Sediaan gel juga bersifat tahan lama, tidak berbau dan tidak mengiritasi kulit. Pada penelitian ini getah buah pepaya akan diformulasi dalam bentuk sediaan gel, dengan basis Na-CMC menghasilkan gel yang jernih, $\mathrm{pH}$ netral. Pada 
formula gel ini digunakan pula propilenglikol sebagai pelembab yang akan meningkatkan kelembaban dengan mempercepat regenerasi kulit yang pecah-pecah.

\section{METODE PENELITIAN}

\section{Alat dan Bahan}

Bahan-bahan yang digunakan dalam penelitian ini yaitu serbuk getah pepaya, natrium karboksimetilselulosa (Na-CMC), gliserin, propilenglikol, trietanolamina (TEA), DMDM Hidantoin, aquadest, dan jeruk nipis. Alat yang digunakan dalam penelitian ini yaitu mortar dan stamper, penangas air, erlenmeyer, batang pengaduk, sendok tanduk, timbangan, gelas ukur, pipet tetes, $\mathrm{pH}$ kertas indikator.

\section{Jalannya Penelitian}

\section{Optimasi Basis Gel}

Optimasi basis gel bertujuan untuk mencari konsenstrasi Na-CMC yang optimal. Konsentrasi yang di uji yaitu 3\%, 4\% dan 5\%. Optimasi gel ini di uji tanpa zat khasiat.

\section{Formulasi gel serbuk getah pepaya}

Gel dibuat dalam 3 formulasi yang dibedakan konsentrasi serbuk getah pepaya. Masingmasing gel mengandung serbuk getah pepaya sebesar 4\%, 5\%, dan $6 \%$ dalam komposisi basis yang sama.

Tabel I. Formulasi gel serbuk getah pepaya

\begin{tabular}{llll}
\hline Nama Bahan & $\begin{array}{l}\text { F1 } \\
(\boldsymbol{\%})\end{array}$ & $\begin{array}{l}\text { F2 } \\
(\boldsymbol{\%})\end{array}$ & $\begin{array}{l}\text { F3 } \\
(\boldsymbol{\%})\end{array}$ \\
\hline Na-CMC & 3 & 3 & 3 \\
Gliserin & 10 & 10 & 10 \\
Propilenglikol & 5 & 5 & 5 \\
TEA & 1 & 1 & 1 \\
DMDM & 0,6 & 0,6 & 0,6 \\
Hidantoin & & & \\
\hline
\end{tabular}




\begin{tabular}{llll}
\hline $\begin{array}{l}\text { Serbuk getah } \\
\text { papaya }\end{array}$ & 4 & 5 & 6 \\
Ad just pH & 7 & 7 & 7 \\
Aquadest ad & 100 & 100 & 100 \\
\hline
\end{tabular}

\section{HASIL DAN PEMBAHASAN}

1. Optimasi Basis Gel

Pada saat optimasi basis gel selama 3 minggu tidak menunjukan perubahan apapun baik dari warna, bau, $\mathrm{pH}$, dan kekentalannya. Namun hasil dari optimasi gel ini menunjukan perbedaan pada setiap formulasi. Warna pada formulasi 1 , 2, dan 3 cenderung sama yaitu bening.

Basis yang didapat selanjutnya diukur nilai $\mathrm{pH}$ nya menggunakan indikator $\mathrm{pH}$ universal. Nilai $\mathrm{pH}$ yang didapat yaitu 8 , yang berarti basis gel basa. Apabila ingin mendapatkan $\mathrm{pH}$ yang diinginkan yaitu 7 , maka diperlukan penyesuaian $\mathrm{pH}$ dengan penambahan air jeruk nipis agar diperoleh $\mathrm{pH}$ yang diinginkan. Jeruk nipis digunakan untuk penambah asam karena mengandung asam sitrat alami. Asam sitrat secara luas digunakan dalam formulasi farmaceutical sering digunakan untuk menambah $\mathrm{pH}$ dari sediaan. Asam sitrat juga telah menunjukkan pada peningkatan kestabilan pada sediaan. Basis gel yang optimum dari segi kekentalan, organoleptis maupun hasil uji $\mathrm{pH}$ diperoleh pada Na-CMC $3 \%$.

2. Evaluasi Gel Serbuk Getah Pepaya

Evaluasi sediaan gel meliputi pengamatan secara organoleptis, homogenitas, dan $\mathrm{pH}$.

Tabel II. Pengamatan organoleptis pada hari ke 0

\begin{tabular}{|c|c|c|c|c|}
\hline Formula & Warna & $\mathrm{Bau}$ & Kekentalan & Homogenitas \\
\hline F1 & Tidak & $\mathrm{Bau}$ & Massa & Homogen \\
\hline & berwarna & khas & kental & \\
\hline F2 & Tidak & $\mathrm{Bau}$ & Massa & Homogen \\
\hline & berwarna & khas & kental & \\
\hline F3 & $\begin{array}{l}\text { Tidak } \\
\text { berwarna }\end{array}$ & $\begin{array}{l}\text { Bau } \\
\text { khas }\end{array}$ & $\begin{array}{c}\text { Massa } \\
\text { Kental }\end{array}$ & Homogen \\
\hline
\end{tabular}

Pengujian $\mathrm{pH}$ dilakukan dengan menggunakan kertas indikator. Pengujian $\mathrm{pH}$ bertujuan untuk melihat tingkat keasaman sediaan gel untuk menjamin sediaan gel tidak menyebabkan iritasi pada kulit.

Tabel III. Hasil uji pH formula gel serbuk getah pepaya

\begin{tabular}{lll}
\hline Formula & $\mathrm{pH}$ Awal & $\mathrm{pH}$ Akhir \\
\hline F1 & 7 & 7 \\
F2 & 7 & 7 \\
F3 & 7 & 7 \\
\hline
\end{tabular}


Pengukuran pH pada gel serbuk getah pepaya diamati pada hari ke 1, 3, 7, 14, 21, dan hari ke 28. Pada pemeriksaan $\mathrm{pH}$ diketahui bahwa yang menyebabkan sediaan itu basa adalah TEA, karena TEA adalah basa lemah sehingga mendapatkan pH 9. Namun pada percobaan ini menggunakan bahan asam sitrat alami yang di dapat dari air jeruk nipis. Hasil menunjukan stabil bahwa dari hari pertama sampai hari terakhir tetap menunjukan $\mathrm{pH} 7$, hal ini karena buffering agent yang digunakan adalah jeruk nipis. Jeruk nipis selain digunakan sebagai bahan penyangga digunakan juga sebagai pengawet dan anti oksidan.

3. Uji Stabilitas Fisik Gel Serbuk Getah Pepaya

Uji stabilitas diperlukan untuk mengetahui kemampuan gel untuk bertahan dalam batas yang ditetapkan sepanjang periode penyimpanan dan penggunaan, sifat dan karakteristiknya sama dengan yang dimilikinya pada saat dibuat. Faktor lingkungan seperti suhu (temperatur), radiasi, cahaya, udara (terutama oksigen, karbondioksida dan uap air) dan kelembaban dapat mempengaruhi stabilitas.

Berdasarkan hasil pengamatan yang dilakukan terhadap sediaan gel serbuk getah pepaya pada penyimpanan suhu lemari pendingin $10^{\circ} \mathrm{C}$ dan pada suhu kamar $30^{\circ} \mathrm{C}$. Bahwa pada suhu lemari pendingin $10^{\circ} \mathrm{C}$ formula sediaan gel serbuk getah pepaya dengan konsentrasi 4\%, 5\% dan 6\% tidak mengalami perubahan warna dan bau. Tetapi sediaan gel mengalami perubahan pada kekentalan yaitu gel menjadi padat dimulai pada hari ke 3. Hal ini disebabkan karena suhu dingin sehingga menyebabkan gel berubah menjadi padat.

Pada suhu kamar $30^{\circ} \mathrm{C}$ diketahui formula sediaan gel serbuk getah pepaya dengan konsentrasi getah pepaya yaitu $4 \%$ dan $5 \%$ tidak mengalami perubahan kekentalan, warna, dan bau. Artinya bahwa sediaan gel yang dibuat stabil secara fisik. Tetapi sediaan gel dengan konsentrasi serbuk getah pepaya 6\% mengalami perubahan kekentalan dimana terjadi pemisahan fase dimulai pada hari ke 14. Hal ini disebabkan karena dengan adanya pemanasan matriks gel akan sedikit longgar sehingga berpengaruh pada kekentalan, jika ikatan longgar Na-CMC turun akan menyebabkan sediaan berubah menjadi encer.

4. Uji cycling test

Gel disimpan pada suhu $10^{\circ} \mathrm{C}$ selama 24 jam lalu dikeluarkan dan ditempatkan pada suhu $30^{\circ} \mathrm{C}$ selama 24 jam. Perlakuan ini adalah satu siklus. Percobaan diulang sebanyak 3 siklus.

Tabel IV. Hasil Uji Cycling Test

\begin{tabular}{ll}
\hline Formula & Hasil \\
\hline F1 & Tidak terjadi sineresis \\
F2 & Tidak terjadi sineresis \\
F3 & Tidak terjadi sineresis \\
\hline
\end{tabular}


Berdasarkan tabel di atas bahwa gel serbuk getah pepaya tidak mengalami sineresis, hal ini menunjukan bahwa pada penyimpanan suhu $10^{\circ} \mathrm{C}$ dan suhu $30^{\circ} \mathrm{C}$ stabil. Sineresis adalah proses dimana cairan terpisah dari gel. Penyebab sineresis yaitu sediaan terlalu lama diletakkan atau disimpan di udara terbuka, dan kenaikan suhu. Hal ini mengakibatkan adanya kontraksi di dalam massa gel. Cairan yang terjerat akan keluar dan berada di atas permukaan gel. Adanya perubahan pada ketegaran gel akan mengakibatkan jarak antar matriks berubah, sehingga memungkinkan cairan bergerak menuju permukaan.

5. Uji Hedonik gel serbuk getah pepaya

Pengujian sediaan gel serbuk getah pepaya yang dilakukan adalah uji hedonik (uji kesukaan).

Tabel V. Persentasi hasil uji hedonik formula gel serbuk getah pepaya pada responden sebanyak 52 orang

\begin{tabular}{|c|c|c|c|c|c|}
\hline \multirow[b]{2}{*}{ SAMPEL } & \multicolumn{5}{|c|}{ HASIL PENILAIAN (\%) } \\
\hline & SSS & $\mathrm{SS}$ & $\mathrm{S}$ & $\mathrm{TS}$ & STS \\
\hline $\mathrm{F} 1$ & 5,8 & 32,7 & 59,6 & 1,9 & 0 \\
\hline $\mathrm{F} 2$ & 1,9 & 27 & 69,2 & 1,9 & 0 \\
\hline F3 & 13,5 & 23 & 59,6 & 3,8 & 0 \\
\hline
\end{tabular}

Tabel VI. Data hasil penelitian pada uji hedonik berdasarkan skala numerik dan urutan tingkat kesukaan responden

\begin{tabular}{llll}
\hline SAMPEL & JUMLAH & PRESENTASE $(\%)$ & URUTAN \\
\hline F1 & 178 & 68,46 & II \\
F2 & 169 & 65 & III \\
F3 & 180 & 69,23 & I \\
\hline
\end{tabular}

Penilaian uji hedonik dilihat secara keseluruhan secara organoleptis meliputi kekentalan, warna dan bau dari gel. Dari hasil uji hedonik, gel pada formula 3 paling disukai responden, tetapi jika dilihat dari uji stabilitas fisik gel formula 3 tidak stabil dibandingkan dengan gel pada formula 1 dan 2 .

\section{KESIMPULAN}

1. Konsentrasi basis gel serbuk getah pepaya yang optimum diperoleh pada konsentrasi NaCMC $3 \%$.

2. Berdasarkan uji stabilitas secara organoleptis, dan uji $\mathrm{pH}$ bahwa gel serbuk getah pepaya dengan konsentrasi $4 \%$ dan $5 \%$ stabil pada penyimpanan suhu kamar $30^{\circ} \mathrm{C}$ selama 28 hari. Hasil uji cycling test menyatakan bahwa ketiga formula yang mengandung serbuk getah pepaya $4 \%, 5 \%$, dan $6 \%$ tidak mengalami sineresis. 
3. Dilihat dari uji stabilitas fisik, uji cycling test dan uji hedonik dapat disimpulkan bahwa gel formula 1 dengan konsentrasi serbuk getah pepaya sebesar $4 \%$ merupakan formulasi paling baik sebagai gel untuk pengobatan tumit pecah-pecah.

\section{DAFTAR PUSTAKA}

Depkes RI. (1995) : Farmakope Indonesia, Edisi Keempat, Penerbit Dirjen POM, Jakarta, $175,378,452$.

Depkes RI. (1978) : Formularium Nasional, Edisi Kedua, Penerbit Dirjen POM, Jakarta, 315. Howard C Ansel (1989) : Pengantar Bentuk Sediaan Farmasi, Edisi Keempat, Penerbit Universitas Indonesia Press, Jakarta, 390-395.

Lachman, L., H. Lieberman, J.L. Kaning. (1994) : Teori dan Praktek Farmasi Industry, Edisi Kedua. Terj dari, The Theory and Practice of Industrial Pharmacy, oleh Siti Suyatmi. UL pres, Jakarta, 1081,1095-1098.

Muljana Wahyu. (2006) : Bercocok Tanam Pepaya, Penerbit Aneka Ilmu, Semarang, 1- 6. NS Salika. (2010) : Serba Serbi kesehatan Perempuan, Penerbit Bukune, Jakarta selatan, 63. Raymond C Rowe, dkk.( 2009) : Handbook of Pharmaceutical Exipients, sixth edition.

Surprapti Lies M. (2005) : Aneka Olahan Pepaya Mentah dan Mengkal, Penerbit Kanisius, Yogyakarta, 16-17

Umi Sri, S. (2014) : Formulasi Sediaan Gel Dari Ekstrak Lidah Buaya, Daun Pandan dan Daun Sirih Sebagai Anti Nyamuk, Karya Tulis Ilmiah, Akademi Farmasi Muhammadiyah Kuningan. Halaman 25-28. 